3-бөлім

Информатика

IRSTI 28.23 .13
Раздел 3

Section 3

Информатика
Computer

Science

DOI: https://doi.org/10.26577/JMMCS.2021.v112.i4.08

\title{
NATURAL LANGUAGE PROCESSING METHODS FOR CONCEPT MAP MINING: THE CASE FOR ENGLISH, KAZAKH AND RUSSIAN TEXTS
}

Concept maps are used for knowledge visualization via representing an input text or domain at the conceptual level. Concept maps reflect the systemic relations between key concepts of a text/ domain and thereby contribute to a deeper understanding of text/domain ideas, save time spent on reading and analysis. However, the process of concept maps construction is laborious and time consuming. Currently, there is a lot of research on the idea of automatic generation concept map from natural language texts. The problem has a high practical value, but in theoretical terms, methods for its solution are mainly language-dependent. Such methods require high-quality annotated linguistic resources, which is a serious problem for low-resource languages like Kazakh. In this work, we analyze the issues related to language-dependent approaches and present our experimental work on automatic generating concept maps from English, Kazakh and Russian texts. We use a well-known language-dependent method called ReVerb which was originally developed for English, and on the example of this method we explore the issues that we have encountered in the case of Kazakh and Russian languages.

Key words: concept maps, concept map mining, natural language processing, low-resource languages, $\mathrm{R}$ language.

А.Б. Нугуманова ${ }^{1}$, А.С. Тлебалдинова ${ }^{1 *}$, Е.М. Байбурин ${ }^{1}$, Е.В. Понькина ${ }^{2}$

${ }^{1}$ Сәрсен Аманжолов атындағы Шығыс Қазақстан университеті, Қазақстан, Өскемен қ.

${ }^{2}$ Алтай мемлекеттік университеті, Ресей, Барнаул қ.

*e-mail: a tlebaldinova@mail.ru

Концепт-карталарды өндіруге арналған табиғи тілді өңдеу әдістері: ағылшын, қазақ және орыс мәтіндерінің мысалында

Концепт-карталар концептуалды деңгейде кіріс мәтінін немесе пәндік аймақты ұсыну арқылы білімді визуализациялау үшін қолданылады. Концепт-карталар мәтіннің/пәндік аймақтың негізгі ұғымдары арасындағы жүйелік қатынасты көрсетеді және сол арқылы оқу мен талдауға кететін уақытты үнемдей отырып, пәндік аймақтың идеяларын тереңірек түсінуге ықпал етеді. Алайда, концепт-карталарды құру процесі еңбек пен және уақытты көп қажет етеді. Қазіргі уақытта табиғи тілдегі мәтіндерден концепт-карталарды автоматты түрде құру идеясына байланысты көптеген зерттеулер жүргізілуде. Мәселе жоғары практикалық құндылыққа ие, бірақ теориялық тұрғыдан оны шешу әдістері негізінен тілге тәуелді. Мұндай әдістер аннотациялары бар сапалы лингвистикалық ресурстарды талап етеді, бұл қазақ тілі сияқты ресурстары шектеулі тілдер үшін елеулі қиындық туғызады. Бұл жұмыста тілге тәуелді тәсілдерге байланысты проблемаларға талдау жасалған және ағылшын, қазақ, 
орыс тілдеріндегі мәтіндерден концепт-карталарды автоматты түрде құру бойынша жасалған эксперименттік жұмыс ұсынылған. Көпшілікке белгілі бастапқыда ағылшын тілі үшін әзірленген тілге тәуелді ReVerb әдісін қолданамыз және осы әдістің мысалында оны қазақ және орыс тілдеріне аудару мәселелерін талдаймыз.

Түйін сөздер: концепт-карталар, концепт-картаны өндіру, табиғи тілді өңдеу, ресурстары шектеулі тілдер, R тілі.

\author{
А.Б. Нугуманова ${ }^{1}$, А.С. Тлебалдинова ${ }^{1 *}$, Е.М. Байбурин ${ }^{1}$, Е.В. Понькина ${ }^{2}$ \\ ${ }^{1}$ Восточно-Казахстанский университет имени Сарсена Аманжолова, Казахстан, г.Усть-Каменогорск \\ ${ }^{2}$ Алтайский государственный университет, Российская Федерация, г.Барнаул \\ *e-mail: a tlebaldinova@mail.ru \\ Методы обработки естественного языка для извлечения концепт-карт: кейс для текстов \\ на английском, казахском и русском языках
}

\begin{abstract}
Концепт-карты используются для визуализации знаний посредством представления входного текста или предметной области на концептуальном уровне. Концепт-карты отражают системные отношения между ключевыми понятиями текста/предметной области и тем самым способствуют более глубокому пониманию идей предметной области, экономя время, затрачиваемое на чтение и анализ. Однако сам процесс построения концептуальных карт трудоемок и требует много времени. В настоящее время проводится много исследований, связанных с идеей автоматической генерации концепт-карт из текстов на естественном языке. Задача имеет высокую практическую ценность, но теоретически методы ее решения в основном являются языко-зависимыми. Такие методы требуют качественных лингвистических ресурсов с аннотациями, что представляет серьезную трудность для таких малоресурсных языков, как казахский. В этой работе мы анализируем проблемы, связанные с языко-зависимыми подходами, и представляем нашу экспериментальную работу по автоматической генерации концептуальных карт из текстов на английском, казахском и русском языках. Мы используем хорошо известный, языко-зависимый метод ReVerb, который изначально был разработан для английского языка, и на примере этого метода анализируем проблемы его переноса на казахский и русский язык.
\end{abstract}

Ключевые слова: концепт-карты, извлечение концепт-карт, обработка естественного языка, малоресурсные языки, язык R.

\title{
1 Introduction
}

As powerful knowledge visualization tools, concept maps allow representing a text and its domain at a conceptual level. They link the key concepts and ideas of a text into a single conceptual framework, which is a kind of guide to a given text and contributes to a deeper understanding of it. Well-built concept maps allow reducing the mental and physical stress on a human, saving time spent on reading and analyzing. The latter actualizes the problem of automatic generation and embedding of concept maps into digital reading services. The problem is at the junction of three disciplines at once - human-computer interaction, natural language processing and digital reading, and largely inherits the challenges of each of them. First, there are challenges posed by the high creative variability inherent in the concept mapping process. There is no single correct way of constructing concept maps, and therefore no unambiguous assessment criteria: this is a creative process, during which new ideas and new, previously non-verbalized relations are generated [2]. Second, there are the challenges posed by traditional natural language processing issues. Generating concept maps from natural language texts involves solving problems such as text preprocessing, open information 
extraction, co-reference resolution, etc. [3]. Third, these are the challenges caused by the novelty of the problem of digital reading [4].

Taken together, all these challenges determine the scientific complexity of the problem of automatic generation of concept maps from natural language texts. They determine the fact that, despite the enormous practical significance, in theoretical terms, this problem is not fully resolved. In this article, we review 20 years of research it the field of automatic concept map generation and analyze the issues related to language-dependent approaches such as ReVerb [5]. We use a well-known language-dependent method called ReVerb which was originally developed for English, and on the example of this method we explore the issues that we have encountered in the case of Kazakh and Russian languages.

\section{Related work}

During the period from 2001 to 2020, about fifty works were published, directly related to the topic of automatic construction of concept maps based on texts in natural language. Table 1 presents 45 of the most famous publications, of which 24 are conference reports, 20 are journal articles, and 1 is a doctoral dissertation. Previously, these publications were compared with publications included in the review of related works given in [44]. The authors of this thorough and in-depth review covered the period from 2001 to 2016 and highlighted 30 relevant publications; this table supplements their overview with uncovered years and works. Most of the publications listed in the table use methods of morphological and syntactic analysis to identify concepts and relations contained in the text [6,7], [11, 12], [18], [20], [22], [25-27], [29,30], [36], [38], [40-42]. Typically, these are techniques such as POS tagging, syntax tree building, and morpho-syntactic patterns extraction. These methods are often supplemented by co-reference resolution, synonym extraction, and named entity recognition $[6,18,26,27,30,36,40]$. Several publications use the search for association rules to extract relations $[9,28,39,50]$.

The extracted concepts and relations are often grouped into larger categories and/or ranked in order of importance. For grouping, as a rule, clustering methods are used $[6,16,30$, 32], and for ranking - statistical methods such as TF-IDF [32, 36, 42, 48, 49], LSA [6, 17, 32], PCA [16], HARD [39], VF-ICF [30], two articles use a method for measuring bursts in text streams $[42,49]$.

Ultimately, the most significant concepts and the relations connecting them are combined into a single map, which from the mathematical point of view is a graph [39, 49]. In most publications, this stage is not described or described superficially, with the exception of [49], in which the construction of the graph is considered as NP-complete optimization problem with constraints imposed on the size and connectivity of the graph, and with an objective function that maximizes the total significance of vertices and edges included in the graph. It should be noted that [49] is notable not only for the detailed consideration of the final stage of assembling a concept map from previously extracted fragments (by constructing a graph). The author of this work also painstakingly considers all stages of generating concept maps, and combines them into a single logical scheme, consisting of five subtasks of the first level and eight subtasks of the second level (Figure 1). Through its comprehensive decomposition, the scheme provides a universal basis for comparing different approaches. 
Table 1: List of related research for the period of 2001-2020

\begin{tabular}{|c|c|}
\hline Year & Publication title, reference \\
\hline 2001 & Automatic reading and learning from text [6] \\
\hline 2002 & Knowledge discovery from texts: a concept frame graph approach [7] \\
\hline 2003 & $\begin{array}{l}\text { Concept maps as visual interfaces to digital libraries: summarization, } \\
\text { collaboration, and automatic generation [8] }\end{array}$ \\
\hline 2004 & A new approach for constructing the concept map [9] \\
\hline 2005 & $\begin{array}{l}\text { Using concept maps in digital libraries as a cross-language resource discovery } \\
\text { tool [10] }\end{array}$ \\
\hline \multirow[t]{2}{*}{2006} & $\begin{array}{l}\text { Jump-starting concept map construction with knowledge extracted from } \\
\text { documents }\end{array}$ \\
\hline & Concept mining for indexing medical literature [12] \\
\hline 2007 & A new approach for constructing the concept map [13] \\
\hline \multirow{5}{*}{2008} & $\begin{array}{l}\text { Automatically constructing concept maps based on fuzzy rules for adapting } \\
\text { learning systems [14] }\end{array}$ \\
\hline & Building domain ontologies from text for educational purposes [15] \\
\hline & Mining e-Learning domain concept map from academic articles [16] \\
\hline & Concept map mining: A definition and a framework for its evaluation [17] \\
\hline & $\begin{array}{l}\text { Mining knowledge from natural language texts using fuzzy associated concept } \\
\text { mapping [18] }\end{array}$ \\
\hline \multirow{3}{*}{2009} & Concept extraction from student essays, towards concept map mining [19] \\
\hline & Toward a fuzzy domain ontology extraction method for adaptive e-learning [20] \\
\hline & A concept map extractor tool for teaching and learning [21] \\
\hline \multirow{3}{*}{2010} & Concept Maps core elements condidates recongnition from text [22] \\
\hline & $\begin{array}{l}\text { Mining concept maps from news stories for measuring civic scientific literacy } \\
\text { in media [23] }\end{array}$ \\
\hline & $\begin{array}{l}\text { Analysis of a Gold Standard for Concept Map Mining - How Humans } \\
\text { Summarize Text Using Concept Maps [24] }\end{array}$ \\
\hline 2011 & Generating concept map exercises from textbooks $[25]$ \\
\hline \multirow[t]{2}{*}{2012} & $\begin{array}{l}\text { The automatic creation of concept maps from documents written using } \\
\text { morphologically rich languages [26] }\end{array}$ \\
\hline & $\begin{array}{l}\text { English2mindmap: An automated system for mindmap generation from } \\
\text { English text [27] }\end{array}$ \\
\hline \multirow[t]{3}{*}{2013} & $\begin{array}{l}\text { Constructing concept maps for adaptive learning systems based on data mining } \\
\text { techniques [28] }\end{array}$ \\
\hline & $\begin{array}{l}\text { Document analysis based automatic concept map generation for enterprises } \\
{[29]}\end{array}$ \\
\hline & Concept map construction from text documents using affinity propagation [30] \\
\hline
\end{tabular}




\begin{tabular}{|c|c|}
\hline Year & Publication title, reference \\
\hline \multirow{4}{*}{2014} & $\begin{array}{l}\text { A practical approach for automatically constructing concept map in e-learning } \\
\text { environments [31] }\end{array}$ \\
\hline & Automatic concept maps generation in support of educational processes [32] \\
\hline & Burst analysis of text document for automatic concept map creation [33] \\
\hline & $\begin{array}{l}\text { Evaluation of concept importance in concept maps mined from lecture notes } \\
{[34]}\end{array}$ \\
\hline \multirow{4}{*}{2015} & Burst analysis for automatic concept map creation with a single document [35] \\
\hline & $\begin{array}{l}\text { Implementation of method for generating concept map from unstructured text } \\
\text { in the Croatian language [36] }\end{array}$ \\
\hline & $\begin{array}{l}\text { An automatic construction of concept maps based on statistical Text Mining } \\
\text { [37] }\end{array}$ \\
\hline & Exploiting concept map mining process for e-content development [38] \\
\hline \multirow{2}{*}{2016} & Using prerequisites to extract concept maps from textbooks [39] \\
\hline & Automatic construction of concept maps from texts [40] \\
\hline \multirow[t]{2}{*}{2017} & $\begin{array}{l}\text { Bringing structure into summaries: crowdsourcing a benchmark corpus of } \\
\text { concept maps [41] }\end{array}$ \\
\hline & Utilizing automatic predicate-argument analysis for concept map mining [42] \\
\hline \multirow[t]{2}{*}{2018} & $\begin{array}{l}\text { Research on a new automatic generation algorithm of concept map based on } \\
\text { text clustering and association rules mining [43] }\end{array}$ \\
\hline & Towards technological approaches for concept maps mining from text [44] \\
\hline \multirow{5}{*}{2019} & Improving an AI-based algorithm to automatically generate concept maps [45] \\
\hline & Concept map mining approach based on the mental models retrieval [46] \\
\hline & Fuzzy concept map generation from academic data sources [47] \\
\hline & $\begin{array}{l}\text { Using a recommender system to suggest educational resources and drawing a } \\
\text { semi-automated concept map to enhance the learning progress [48] }\end{array}$ \\
\hline & Automatic structured text summarization with concept maps [49] \\
\hline 2020 & $\begin{array}{l}\text { Research on a new automatic generation algorithm of concept map based on } \\
\text { text analysis and association rules mining [50] }\end{array}$ \\
\hline
\end{tabular}

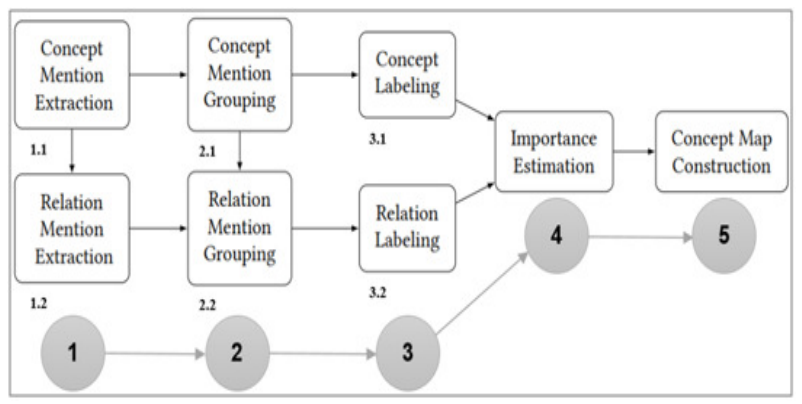

Figure 1: General scheme for solving the problem of automatic generation of concept maps from texts in natural language [49] (task numbering is ours) 


\section{Material and methods}

\subsection{ReVerb relation extraction method}

Over the past two decades, the solution to the problem of automatic generation of concept maps from natural language texts has been largely based on the methods of parsing. Since these methods are language-dependent, the degree of their elaboration directly depends on the status and resource availability of the language used. Most of the cited publications use language-dependent methods designed for English language [39,48]. In other words, there is a clear imbalance not only between language-dependent and language-independent methods of generating concept maps (not in favor of the latter), but also between high-resource and low-resource languages (also not in favor of the latter).

ReVerb which we use in this work, is exactly the kind of such language-dependent methods. It takes as input a POS-tagged sentence and returns a set of $(x, r, y)$ extraction triples [5]. The method first identifies relation phrases that satisfy syntactic and lexical constraints, and then finds a pair of entities (noun phrases) for each relation phrase. The method retrieves only sequences of tokens expressing a verb relation located between two entities, for example: "We trust in God". The method does not provide relations that are located differently in the text, for example: "In God we trust". Given an input sentence $s$, ReVerb follows the next algorithm:

- Step 1. For each verb $v$ in the sentence $s$, find the longest sequence of words $r_{v}$ such that

$-r_{v}$ starts at the verb $v$,

$-r_{v}$ satisfies the syntactic constraint,

- $r_{v}$ satisfies the lexical constraint.

- $r_{v}$ satisfies the lexical constraint. If any pair of verbal sequences $r_{v 1}$ and $r_{v 2}$ are adjacent or overlap in the sentence $s$, they are merged into a single sequence. Therefore, the relation phrase must be a contiguous span of words in the sentence.

- Step 2. For each relation phrase $r$ identified in Step 1,

- find the nearest noun phrase $x$ to the left of $r$ in a sentence $s$ such that $x$ is not a relative pronoun,

- find the nearest noun phrase $y$ to the right of $r$ in a sentence $s$. If such an $(x, y)$ pair could be found, return $(x, r, y)$ as an extraction.

The syntactic constraint requires for English relation phrases to match POS-tag patterns such as V (a verb, e.g., write), VP (a verb followed by a preposition, e.g., written by), VN?P (a verb followed by a noun and ended with a preposition, e.g., is a part of), and so forth. The lexical constraint separates valid relation phrases from over-specified ones using an external relation database. 


\subsection{Experimental work}

We realize ReVerb method with the help of $\mathrm{R}$ language and UDPipe text processing models. UDPipe it is a pipeline which is based on Universal Dependencies 2.4 Models and provides pre-trained language models for various languages [51]. Experiments on English texts have been carried out using the joint model "english-ewt-ud-2.4-190531". Tokenizer, POS tagger, lemmatizer and parser models have been applied to input texts (see Figure 2). The output was a preprocessed corpus (see Figure 3). Then POS-tagging patterns have been applied to corpus tokens in order to extract relations (verb phrases) and entities (noun phrases). For example, the pattern $<\mathrm{VB}>$ ? $<\mathrm{IN}>$ has been applied to extract relations like "flows" or "flows into", and the pattern $<\mathrm{DT}>$ ? $<\mathrm{PRP}>$ ? $<\mathrm{JJ}>*<\mathrm{NN}>$ has been applied to extract entities like "The Baltic Sea". Matched relations and entities phrases have been sorted in the order they appeared in the sentences, and if they formed a sequence "noun phrase - verb phrase - noun phrase" they have been extracted as a triplet. Finally, a concept map has been constructed from found triplets (see Figure 4).

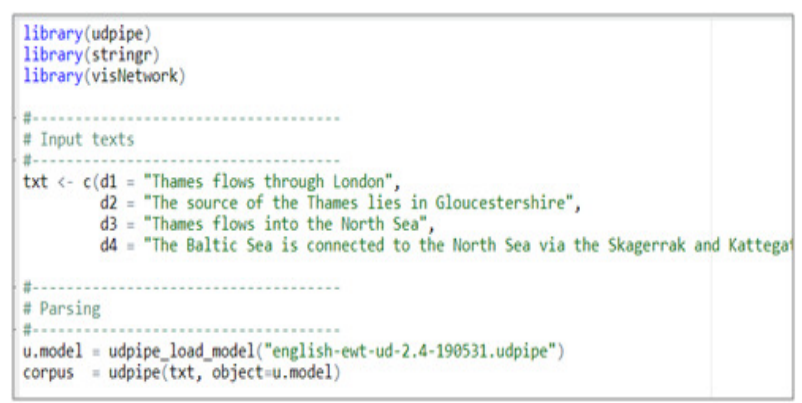

Figure 2: Applying UDPipe to English texts

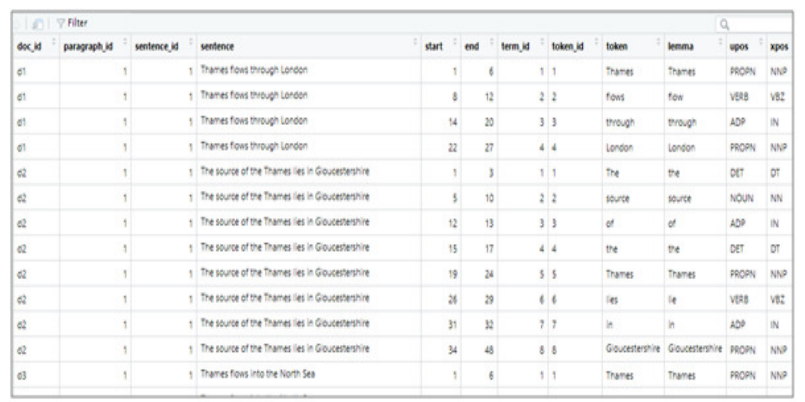

Figure 3: The output of UDPipe for English texts

Experiments on Russian texts have been carried out using the joint model "russian-gsd-ud2.4-190531" from Universal Dependencies 2.4 Models. Tokenizer, POS tagger, lemmatizer and parser models have been applied to input texts (see Figure 5). The output was a preprocessed corpus (see Figures 6-7). The POS-tag patterns, as is the case with English, have been applied to tokens, and a concept map has been constructed from found triplets (see Figure 8). Despite the fact that there are some parsing errors in the corpus, these errors generally do not affect 


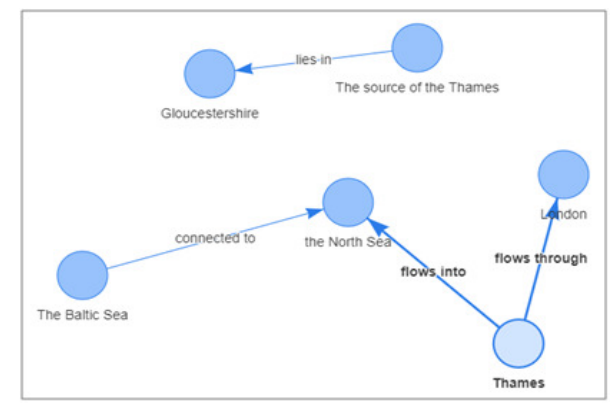

Figure 4: The final concept map based on English texts

the result of extracting relations and entities. Logical errors of the ReVerb algorithm are more serious. In particular, from the sentence "Иртыш несет свои воды в Северный Ледовитый океан" ("Irtysh carries its water to the Arctic Ocean") three entities, viz. "Иртыш" ("Irtysh"), "свои воды" ("its water") and "Северный Ледовитый океан" ("the Arctic Ocean"), and one relation "несет" ("carries") are extracted, so the resulting triplet is constructed as "Иртыш несет - свои воды" ("Irtysh - carries - its water"). However, the correct version should be "Иртыш - несет свои воды в - Северный Ледовитый океан" ("Irtysh - carries its water to - the Arctic Ocean").

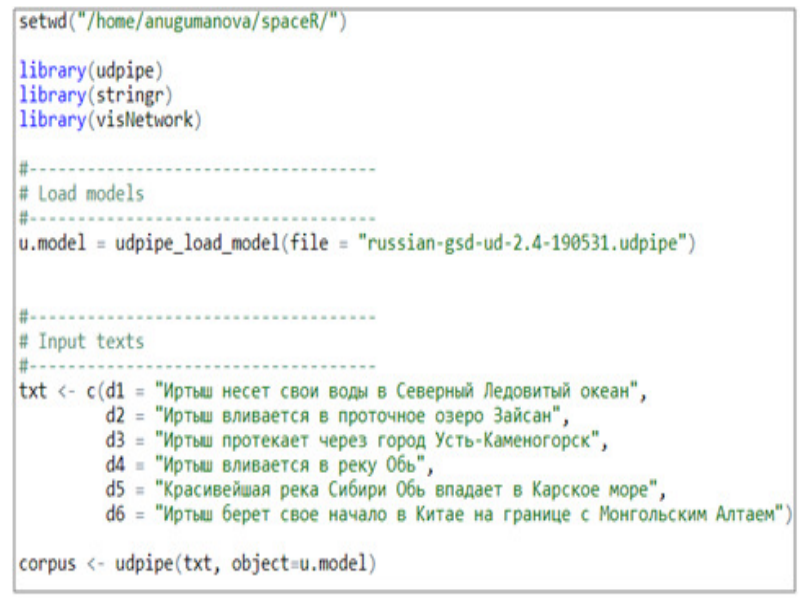

Figure 5: Applying UDPipe to Russian texts

Experiments on Kazakh texts have been carried out using the joint model "kazakh-ud-2.0170801" from Universal Dependencies 2.0 Models (there is no models for Kazakh language in the Universal Dependencies 2.4 Treebank). Tokenizer, POS tagger, lemmatizer and parser models have been applied to input texts (see Figure 9). The output was a preprocessed corpus, and as it shown in Figure 10, there are a number of serious POS tagging errors which leads to a very low performance in triple extraction (see Figure 11). At the same time, manually correcting POS tags results in a more believable concept map (see Figure 12). 


\begin{tabular}{|c|c|c|c|c|}
\hline token & lemma & upes & xpos & feats \\
\hline Uprow & Иртыш & PROPN & NNP & Animacy=Anim/Case $=$ Nom $\mid$ Gender $=$ MasciNumbe \\
\hline recet & mecto & VERB & VBC & Aspect=imp $\mid$ Mood $=$ ind $\mid$ Number $=$ Sing Person $=\left.3\right|^{\circ}$ \\
\hline ceon & сөой & Det & PRPS & Animacy $=$ inan $\mid$ Case $=$ Ace Numbet $=$ Plut \\
\hline $\operatorname{sog} \theta$ & sopa & NOUN & NN & Animacy $=$ inan $|C a s e=A c c|$ Gender $=$ Fem $\mid$ Numbers; \\
\hline 8 & $=$ & ADP & IN & NA \\
\hline Cетермый & setepmoñ & $A D J$ & ル & Animacy $=$ inan $\mid C a s e=$ Acc Degree $=$ Pos Gender $=$ M: \\
\hline รедовитй & Лемсеитый & ADJ & 川 & Animacy $=$ inan $\mid C$ ase $=$ Ace Degree $=$ Pos Gender $=$ M: \\
\hline oxesn & oxesm & NOUN & NN & Animacy $=$ inan $\mid C a s e=$ AcciGender $*$ Masc|Number \\
\hline Uptow & Иproly & PROPN & NNP & Animacy $=$ An im Case $=$ Nom $\mid$ Gender $=$ Masci Numbe \\
\hline onveretca & вмиваться & VERB & VBC & Aspect $=\mid$ imp $\mid$ Mood $=$ ind $\mid$ Number $=$ Sing Person $=37$ \\
\hline 8 & 8 & ADP & IN & NA \\
\hline nporounce & กро:ouneตั & ADJ & ML & 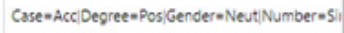 \\
\hline orepo & osepo & NOUN & NN & Animacy $=$ inan $\mid$ Case $=$ Acci Gender $=$ Neut| Number $=$ \\
\hline 3aйcan & звйсзн & NOUN & NN & Animscy $=$ inan $\mid$ Case $=$ Nom $\mid$ Gender $=$ Masc|Number \\
\hline
\end{tabular}

Figure 6: The output of UDPipe for Russian texts

\begin{tabular}{|c|c|c|}
\hline & token & type \\
\hline 1 & Uptow & noun ghrase \\
\hline 4 & ceon toted & noun ghrase \\
\hline 8 & Севернвй Ледовитый океан & noun ghrase \\
\hline
\end{tabular}

Figure 7: Entities (noun phrases) extracted from the sentence "Иртыш несет свои воды в Северный Ледовитый океан"

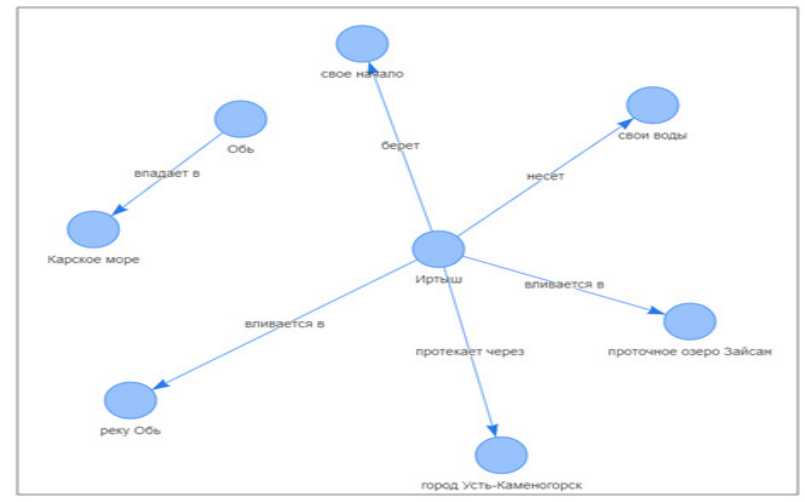

Figure 8: The final concept map based on Russian texts

\section{Conclusion}

In this paper, we considered an algorithm for extracting triplets of the "entity - relation - entity"type from texts in English, Kazakh and Russian. The algorithm is based on the use of syntax patterns and depends on the availability of annotated linguistic resources. It demonstrates acceptable results for Russian and English. However, experiments carried out for Kazakh texts have shown that the algorithm demonstrates very low quality in the 


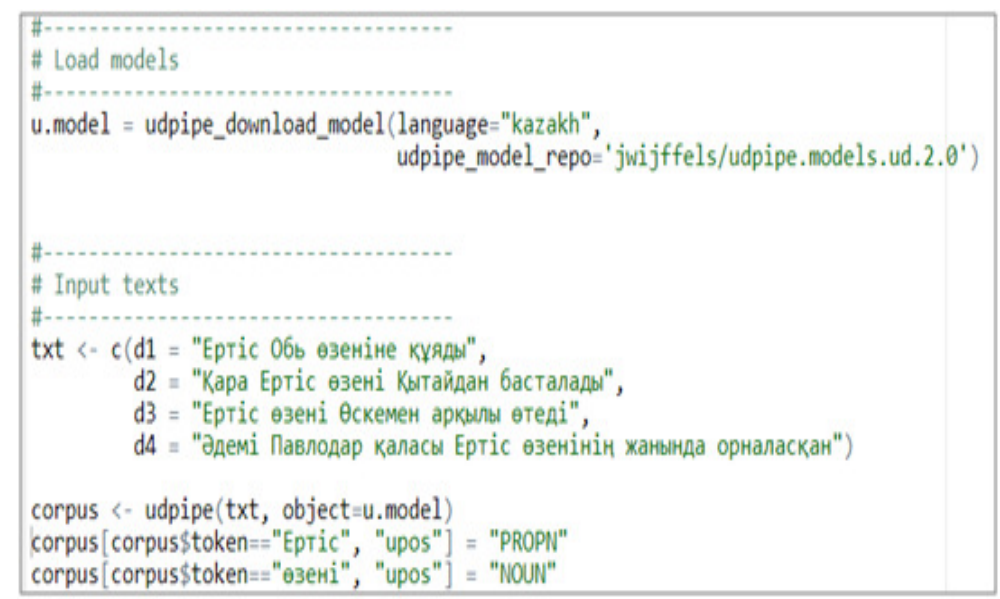

Figure 9: Applying UDPipe to Kazakh texts

\begin{tabular}{|c|c|c|}
\hline token & lemma & upos \\
\hline Epric & Epric & NUM \\
\hline O6॰ & O6b & NouN \\
\hline oserive & esenine & PRON \\
\hline coasow & $w$ & VERB \\
\hline Kaps & Kapa & NOUN \\
\hline Epric & eptic & NUM \\
\hline eseri & esent & ADJ \\
\hline Көтойдат & Котайдан & NOUN \\
\hline
\end{tabular}

Figure 10: The output of UDPipe for Kazakh texts

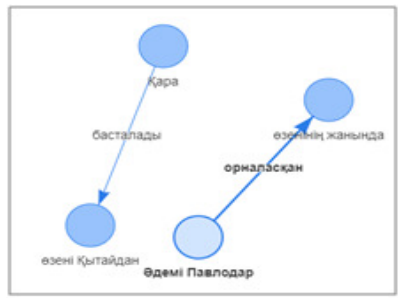

Figure 11: The output of UDPipe for Kazakh texts. An incorrect version of a concept map based on wrong preprocessing of Kazakh texts

absence of such linguistic resources. In our future work, we plan to explore alternative ways of constructing concept maps for low-resource languages such as Kazakh.

\section{Список литературы}

[1] Novak J. D., Canas A. J. "Theoretical origins of concept maps, how to construct them, and uses in education", Reflecting Education 3-1, 2007. - Pp.29-42.

[2] Falke, T. "Automatic Structured Text Summarization with Concept Maps", Doctoral dissertation, Technische Universit?t, 2019. 


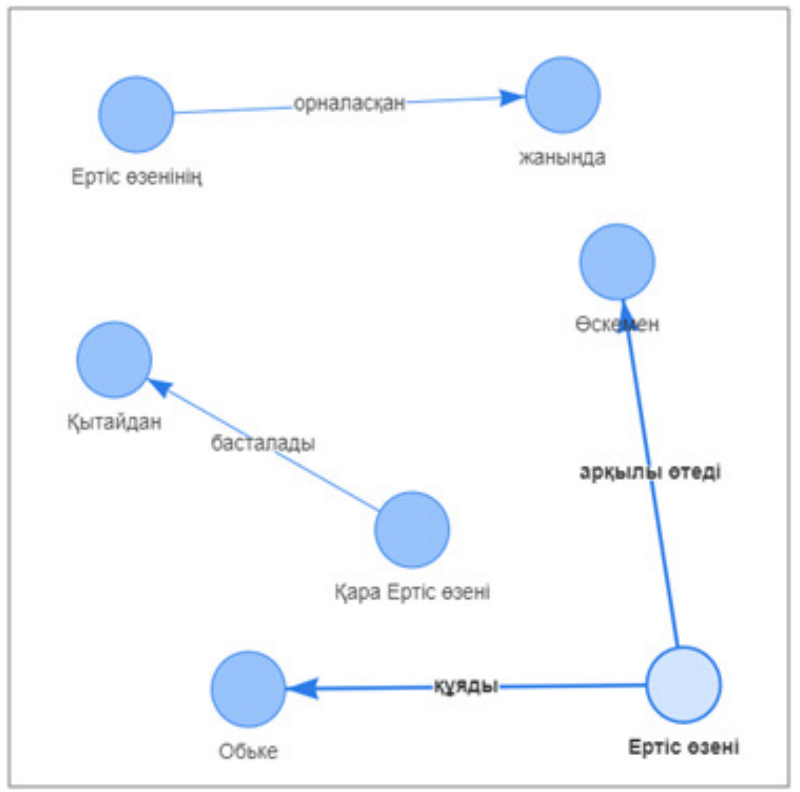

Figure 12: A version of a concept map based on manual preprocessing of Kazakh texts

[3] Kudryavtsev, D., \& Gavrilova, T. "From anarchy to system: A novel classification of visual knowledge codification techniques", Knowledge and Process Management 24, 2017, .- Pp.3-13.

[4] Baron N. "Do students lose depth in digital reading?" - The Conversation. Available at: https://theconversation. com/dostudents-lose-depth-in-digital-reading-61897, 2016.

[5] Fader, A., Soderland S., Etzioni O. "Identifying relations for open information extraction", Proceedings of the 2011 Conference on empirical methods in Natural language processing, 2011, . - Pp.1535-1545.

[6] Oliveira A., Pereira F. C., Cardoso A. "Automatic reading and learning from text", Proceedings of the International Symposium on Artificial Intelligence, 2001.

[7] Rajaraman K., Tan A. H. "Knowledge discovery from texts: a concept frame graph approach", Proceedings of the eleventh international conference on Information and knowledge management, 2002. - Pp.669-671.

[8] Shen R., Richardson R., Fox E. A. "Concept maps as visual interfaces to digital libraries: summarization, collaboration, and automatic generation", Joint Conference on Digital Libraries, 2003.

[9] Sue P. C. et al. A new approach for constructing the concept map //IEEE International Conference on Advanced Learning Technologies, 2004. Proceedings. - IEEE, 2004. - Pp. 76-80.

[10] E. A. Fox and R. Richardson. Using concept maps in digital libraries as a cross-language resource discovery tool. // Proceedings of the 5th ACM/IEEE-CS Joint Conference on Digital Libraries (JCDL '05) - 2005. - Pp. 256-257, doi: $10.1145 / 1065385.1065443$.

[11] Leake, A. \& Valerio D. Jump-starting concept map construction with knowledge extracted from documents. In Proceedings of the Second International Conference on Concept Mapping -2006.

[12] Bichindaritz I., Akkineni S. Concept mining for indexing medical literature //Engineering Applications of Artificial Intelligence. - 2006. - T. 19. - №. 4. - C. 411-417.

[13] S. Tseng, P. C. Sue, J. M. Su, J. F. Weng, \& W. N. Tsai. A new approach for constructing the concept map. Computers \& Education, 49(3). - 2007. -Pp. 691-707. DOI: 10.1016/j.compedu.2005.11.020.

[14] Bai S. M., Chen S. M. Automatically constructing concept maps based on fuzzy rules for adapting learning systems // Expert systems with Applications. - 2008. - Vol. 35.(1-2). - P. 41-49. 
[15] Zouaq A., Nkambou R. Building domain ontologies from text for educational purposes //IEEE Transactions on learning technologies. - 2008. - Vol. 1. - P. 49-62.

[16] Chen N. S. et al. Mining e-Learning domain concept map from academic articles //Computers \& Education. - 2008. Vol. 50. - No. 3. - P. 1009-1021.

[17] Villalon J. J., Calvo R. A. Concept map mining: A definition and a framework for its evaluation //2008 IEEE/WIC/ACM International Conference on Web Intelligence and Intelligent Agent Technology. - IEEE, 2008. - Vol. 3. - P. 357-360.

[18] Wang W. M. et al. Mining knowledge from natural language texts using fuzzy associated concept mapping //Information Processing \& Management. - 2008. - T. 44. - No. 5. - P. 1707-1719.

[19] Villalon J., Calvo R. A. Concept extraction from student essays, towards concept map mining // 2009 Ninth IEEE International Conference on Advanced Learning Technologies. - IEEE, 2009. - Pp. 221-225.

[20] Lau R., Song D., et al. Toward a fuzzy domain ontology extraction method for adaptive E-learning. // IEEE Transactions on Knowledge and Data Engineering. - 2009.- Vol. 21, no. 6. Pp. 800-813. DOI: 10.1109/TKDE.2008.137.

[21] Dalmolin L. et al. A concept map extractor tool for teaching and learning // 2009 Ninth IEEE International Conference on Advanced Learning Technologies. - IEEE, 2009. - P. 18-20.

[22] Kowata, J. H., Cury, D., and Silva Boeres, M. C. Concept Maps core elements condidates recongnition from text. // In Concept Maps: Making Learning Meaningful. Proceedings of the 4th International Conference on Concept Mapping. 2010. - P. 120-127.

[23] Tseng Y. et al. Mining concept maps from news stories for measuring civic scientific literacy in media //Computers \& Education. - 2010. - Vol. 55. - №. 1. - P. 165-177.

[24] Villalon J., Calvo R. A., Montenegro R. Analysis of a gold standard for Concept Map Mining-How humans summarize text using concept maps //Proceedings of the Fourth International Conference on Concept Mapping. - 2010. - P. 14-22.

[25] Olney A., Cade W. L., Williams C. Generating concept map exercises from textbooks //Proceedings of the Sixth Workshop on Innovative Use of NLP for Building Educational Applications. - 2011. - P. 111-119.

[26] Zubrinic K., Kalpic D., Milicevic M. The automatic creation of concept maps from documents written using morphologically rich languages //Expert systems with applications. - 2012. - Vol. 39. - №. 16. - P. 12709-12718.

[27] Elhoseiny M., Elgammal A. English2mindmap: An automated system for mindmap generation from english text //2012 IEEE International Symposium on Multimedia. - IEEE, 2012. - P. 326-331.

[28] S. M. Chen, \& P. J. Sue. Constructing concept maps for adaptive learning systems based on data mining techniques. Expert Systems with Applications, 40(7). - 2013. - P. 2746-2755. DOI: 10.1016/j.eswa.2012.11.018.

[29] Karannagoda E. L. et al. Document analysis based automatic concept map generation for enterprises //2013 International Conference on Advances in ICT for Emerging Regions (ICTer). - IEEE, 2013. - P. 154-159.

[30] Qasim, I., Jeong, J.-W., Heu, J.-U., and Lee, D.-H. Concept Map Construction From Text Documents Using Affinity Propagation. Journal of Information Science, 39(6). - 2013. - P. 719-736.

[31] Yi N., Li H. A practical approach for automatically constructing concept map in E-learning environments //2014 IEEE International Conference on Progress in Informatics and Computing. - IEEE, 2014. - P. 582-586.

[32] Pipitone A., Cannella V., Pirrone R. Automatic concept maps generation in support of educational processes //Journal of e-Learning and Knowledge Society. - 2014. - Vol. 10. - №. 1.

[33] Yoon W.C., Lee S., Lee S. Burst analysis of text document for automatic concept map creation // International Conference on Industrial, Engineering and Other Applications of Applied Intelligent Systems. - Springer, Cham, 2014. - P. 407-416.

[34] Atapattu T., Falkner K., Falkner N. Evaluation of concept importance in concept maps mined from lecture notes //proceedings of the 6th International conference on computer supported education. - 2014. - P. 75-84.

[35] S. Lee, Y. Park, \& W. C Yoon. Burst analysis for automatic concept map creation with a single document. // Expert Systems With Applications, 42(22). - 2015. - P. 8817-8829.

[36] Zubrinic K., Obradovic I., Sjekavica T. Implementation of method for generating concept map from unstructured text in the Croatian language //2015 23rd International Conference on Software, Telecommunications and Computer Networks (SoftCOM). - IEEE, 2015. - P. 220-223. 
[37] Nugumanova A. et al. An Automatic Construction of Concept Maps Based on Statistical Text Mining //International Conference on Data Management Technologies and Applications. - Springer, Cham, 2015. - Pp. 29-38.

[38] Panopoulou et al. Exploiting Concept Map Mining Process For E-Content Development. // 7th International Conference on Education and New Learning Technologies. - 2015.

[39] Wang S. et al. Using prerequisites to extract concept maps from textbooks //Proceedings of the 25th acm international on conference on information and knowledge management. - 2016. - P. 317-326.

[40] Aguiar, C. Z., Cury, D., and Zouaq, A. Automatic Construction of Concept Maps from Texts. In Proceedings of the 7th International Conference on Concept Mapping. - 2016. - P. 20-30.

[41] Falke T., Gurevych I. Bringing structure into summaries: Crowdsourcing a benchmark corpus of concept maps //arXiv preprint arXiv:1704.04452. - 2017.

[42] Falke T., Gurevych I. Utilizing automatic predicate-argument analysis for concept map mining //IWCS 2017-12th International Conference on Computational Semantics. - 2017.

[43] Shao Z. et al. Research on a New Automatic Generation Algorithm of Concept Map Based on Text Clustering and Association Rules Mining //International Conference on Intelligent Computing. - Springer, Cham, 2018. - P. 479-490.

[44] Aguiar C. Z., Cury D., Zouaq A Towards Technological Approaches for Concept Maps Mining from Text //CLEI Electronic Journal. - 2018. - Vol. 21. - №. 1.

[45] Alomari S., Abdullah S. Improving an AI-Based Algorithm to Automatically Generate Concept Maps //Computer and Information Science. - 2019. - Vol. 12. - №. 4. - P. 72-83.

[46] Nacheva R. et al. Concept Map Mining Approach Based on the Mental Models Retrieval //TEM Journal. - 2019. - Vol. 8. - №. 4. - P. 1484.

[47] Ahmed R., Ahmad T. Fuzzy Concept Map Generation from Academic Data Sources //Applications of Artificial Intelligence Techniques in Engineering. - Springer, Singapore, 2019. - P. 415-424.

[48] Mirbagheri G., Hakimian M., Kardan A. A. Using a recommender system to suggest educational resources and drawing a semi-automated concept map to enhance the learning progress //Proceedings of The International Conference on ELearning in the Workplace 2019 (ICELW). - 2019. - Vol. 6.

[49] Falke, T. Automatic Structured Text Summarization with Concept Maps. // Doctoral dissertation.- 2019. - Darmstadt Technische Universit?t. -240 p.

[50] Shao Z. et al. Research on a new automatic generation algorithm of concept map based on text analysis and association rules mining //Journal of Ambient Intelligence and Humanized Computing. - 2020. - Vol. 11. - №. 2. - P. 539-551.

[51] Straka M. and Strakov? J. Universal Dependencies 2.4 Models for UDPipe (2019-05-31), LINDAT/CLARIAH-CZ digital library at the Institute of Formal and Applied Linguistics (?FAL), Faculty of Mathematics and Physics, Charles University, http://hdl.handle.net/11234/1-2998.

\section{References}

[1] Novak J. D., Canas A. J., "Theoretical origins of concept maps, how to construct them, and uses in education" , Reflecting Education 3-1 (2007): 29-42.

[2] Falke, T., "Automatic Structured Text Summarization with Concept Maps", Doctoral dissertation, Technische Universit?t (2019).

[3] Kudryavtsev, D., \& Gavrilova, T., "From anarchy to system: A novel classification of visual knowledge codification techniques", Knowledge and Process Management 24, (2017): 3-13.

[4] Baron N., "Do students lose depth in digital reading?"- The Conversation. Available at: https://theconversation. com/dostudents-lose-depth-in-digital-reading-61897 (2016).

[5] Fader, A., Soderland S., Etzioni O., "Identifying relations for open information extraction", Proceedings of the 2011 Conference on empirical methods in Natural language processing (2011): 1535-1545.

[6] Oliveira A., Pereira F. C., Cardoso A.,"Automatic reading and learning from text", Proceedings of the International Symposium on Artificial Intelligence (2001). 
[7] Rajaraman K., Tan A. H., "Knowledge discovery from texts: a concept frame graph approach" , Proceedings of the eleventh international conference on Information and knowledge management (2002): 669-671.

[8] Shen R., Richardson R., Fox E. A., "Concept maps as visual interfaces to digital libraries: summarization, collaboration, and automatic generation", Joint Conference on Digital Libraries (2003).

[9] Sue P. C. et al., "A new approach for constructing the concept map", IEEE International Conference on Advanced Learning Technologies, Proceedings. - IEEE, (2004):76-80.

[10] E. A. Fox, R. Richardson., "Using concept maps in digital libraries as a cross-language resource discovery tool", Proceedings of the 5th ACM/IEEE-CS Joint Conference on Digital Libraries (JCDL '05) - (2005):256-257, doi: $10.1145 / 1065385.1065443$.

[11] Leake, A. Valerio D., "Jump-starting concept map construction with knowledge extracted from documents", In Proceedings of the Second International Conference on Concept Mapping, (2006).

[12] Bichindaritz I., Akkineni S., "Concept mining for indexing medical literature", Engineering Applications of Artificial Intelligence, V 19, No 4 (2006):411-417.

[13] S. Tseng, P. C. Sue, J. M. Su, J. F. Weng, \& W. N. Tsai, "A new approach for constructing the concept map" , Computers ES Education, 49(3) (2007):691-707. DOI: 10.1016/j.compedu.2005.11.020.

[14] Bai S. M., Chen S. M., "Automatically constructing concept maps based on fuzzy rules for adapting learning systems" , Expert systems with Applications, V. 35(1-2) (2008):41-49.

[15] Zouaq A., Nkambou R., "Building domain ontologies from text for educational purposes", IEEE Transactions on learning technologies, V. 1:49-62.

[16] Chen N. S. et al., "Mining e-Learning domain concept map from academic articles", Computers E Education, V. 50, No 3 (2008):1009-1021.

[17] Villalon J. J., Calvo R. A., "A definition and a framework for its evaluation", 2008 IEEE/WIC/ACM International Conference on Web Intelligence and Intelligent Agent Technology, IEEE, V. 3, (2008):357-360.

[18] Wang W. M. et al., "Mining knowledge from natural language texts using fuzzy associated concept mapping" , Information Processing \&s Management, V. 44 No 5 (2008):1707-1719.

[19] Villalon J., Calvo R. A., "Concept extraction from student essays, towards concept map mining", 2009 Ninth IEEE International Conference on Advanced Learning Technologies. - IEEE, (2009):221-225.

[20] Lau R., Song D., et al., "Toward a fuzzy domain ontology extraction method for adaptive E-learning" , IEEE Transactions on Knowledge and Data Engineering, V. 21 No 6 (2009):800-813. DOI: 10.1109/TKDE.2008.137.

[21] Dalmolin L. et al., "A concept map extractor tool for teaching and learning", 2009 Ninth IEEE International Conference on Advanced Learning Technologies. - IEEE, (2009):18-20.

[22] Kowata, J. H., Cury, D., and Silva Boeres, M. C., "Concept Maps core elements condidates recongnition from text" , In Concept Maps: Making Learning Meaningful. Proceedings of the 4th International Conference on Concept Mapping, (2010):120-127.

[23] Tseng Y. et al, "Mining concept maps from news stories for measuring civic scientific literacy in media" , Computers $\mathcal{E}$ Education, V.55, No 1 (2010):165-177.

[24] Villalon J., Calvo R. A., Montenegro R., "Analysis of a gold standard for Concept Map Mining-How humans summarize text using concept maps", Proceedings of the Fourth International Conference on Concept Mapping, (2010):14-22.

[25] Olney A., Cade W. L., Williams C., "Generating concept map exercises from textbooks", Proceedings of the Sixth Workshop on Innovative Use of NLP for Building Educational Applications, (2011):111-119.

[26] Zubrinic K., Kalpic D., Milicevic M., "The automatic creation of concept maps from documents written using morphologically rich languages", Expert systems with applications, V. 39, No 16 (2012):12709-12718.

[27] S. M. Chen, \& P. J. Sue, "English2mindmap: An automated system for mindmap generation from english text", 2012 IEEE International Symposium on Multimedia, IEEE, (2012):326-331.

[28] Zubrinic K., Kalpic D., Milicevic M., "Constructing concept maps for adaptive learning systems based on data mining techniques", Expert systems with applications, 40(7) (2013):2746-2755. DOI: 10.1016/j.eswa.2012.11.018. 
[29] Karannagoda E. L. et al., "Document analysis based automatic concept map generation for enterprises" , 2013 International Conference on Advances in ICT for Emerging Regions (ICTer), IEEE (2013):154-159.

[30] Qasim, I., Jeong, J.-W., Heu, J.-U., and Lee, D.-H., "Concept Map Construction From Text Documents Using Affinity Propagation", Journal of Information Science, 39(6) (2013):719-736.

[31] Yi N., Li H., "A practical approach for automatically constructing concept map in E-learning environments" , 2014 IEEE International Conference on Progress in Informatics and Computing, IEEE (2014):582-586.

[32] Pipitone A., Cannella V., Pirrone R., "Automatic concept maps generation in support of educational processes" , Journal of e-Learning and Knowledge Society, V.10 No 1 (2014).

[33] Yoon W.C., Lee S., Lee S., "Burst analysis of text document for automatic concept map creation", International Conference on Industrial, Engineering and Other Applications of Applied Intelligent Systems, Springer, Cham (2014):407416.

[34] Atapattu T., Falkner K., Falkner N., "Evaluation of concept importance in concept maps mined from lecture notes", Proceedings of the 6th International conference on computer supported education, (2014):75-84.

[35] S. Lee, Y. Park, \& W. C Yoon., "Burst analysis for automatic concept map creation with a single document" , Expert Systems With Applications, 42(22) (2015):8817-8829.

[36] Zubrinic K., Obradovic I., Sjekavica T., "Implementation of method for generating concept map from unstructured text in the Croatian language", 2015 23rd International Conference on Software, Telecommunications and Computer Networks (SoftCOM), IEEE (2015):220-223.

[37] Nugumanova A. et al., "An Automatic Construction of Concept Maps Based on Statistical Text Mining", International Conference on Data Management Technologies and Applications, Springer, Cham (2015):29-38.

[38] Panopoulou et al., "Exploiting Concept Map Mining Process For E-Content Development" , 7th International Conference on Education and New Learning Technologies (2015).

[39] Wang S. et al., "Using prerequisites to extract concept maps from textbooks", Proceedings of the 25th acm international on conference on information and knowledge management (2016):317-326.

[40] Aguiar, C. Z., Cury, D., and Zouaq, A., "Automatic Construction of Concept Maps from Texts", In Proceedings of the 7th International Conference on Concept Mapping (2016):20-30.

[41] Falke T., Gurevych I., "Bringing structure into summaries: Crowdsourcing a benchmark corpus of concept maps" , rXiv preprint arXiv:1704.04452 (2017).

[42] Falke T., Gurevych I., "Utilizing automatic predicate-argument analysis for concept map mining", IWCS 2017-12th International Conference on Computational Semantics (2017).

[43] Shao Z. et al., "Research on a New Automatic Generation Algorithm of Concept Map Based on Text Clustering and Association Rules Mining", International Conference on Intelligent Computing. - Springer, Cham (2018):479-490.

[44] Aguiar C. Z., Cury D., Zouaq A., "Towards Technological Approaches for Concept Maps Mining from Text", CLEI Electronic Journal, V.21, No 1 (2018).

[45] Alomari S., Abdullah S., "Improving an AI-Based Algorithm to Automatically Generate Concept Maps" , Computer and Information Science, V.12, No 4 (2019):72-83.

[46] Nacheva R. et al., "Concept Map Mining Approach Based on the Mental Models Retrieval", TEM Journal, V.8, No 4 (2019):1484.

[47] Ahmed R., Ahmad T., "Fuzzy Concept Map Generation from Academic Data Sources", Applications of Artificial Intelligence Techniques in Engineering, Springer, Singapore (2019):415-424.

[48] Mirbagheri G., Hakimian M., Kardan A. A., "Using a recommender system to suggest educational resources and drawing a semi-automated concept map to enhance the learning progress", Proceedings of The International Conference on ELearning in the Workplace 2019 (ICELW), V.6 (2019).

[49] Falke, T., "Automatic Structured Text Summarization with Concept Maps", Doctoral dissertation, Darmstadt Technische Universit?t (2019):240.

[50] Shao Z. et al., "Research on a new automatic generation algorithm of concept map based on text analysis and association rules mining", Journal of Ambient Intelligence and Humanized Computing, V.11 No 2 (2020):539-551. 
[51] Straka M. and Strakov? J., "Universal Dependencies 2.4 Models for UDPipe (2019-05-31), LINDAT/CLARIAH-CZ digital library at the Institute of Formal and Applied Linguistics (?FAL)", Faculty of Mathematics and Physics, Charles University, http://hdl.handle.net/11234/1-2998. 